\title{
Animal evaluation of Aries HD perennial ryegrass selected for high digestibility
}

\author{
S.J. BLUETT ${ }^{1}$, J. HODGSON ${ }^{1}$, P.D. KEMP ${ }^{1}$, and T.N. BARRY ${ }^{2}$ \\ ${ }^{1}$ Department of Plant Science, Massey University, Palmerston North \\ ${ }^{2}$ Department of Animal Science, Massey University, Palmerston North
}

\begin{abstract}
Aries HD perennial ryegrass (Lolium perenne L.) has been selected for increased digestibility in summer and early autumn. It is claimed to be the first commercial perennial ryegrass selected specifically for improved digestibility. The relative performance of weaned Romney lambs over summer was compared using Yatsyn 1 perennial ryegrass as a control cultivar. There were 3 replicates of each cultivar of 0.33 ha initially stocked with 8 lambs/plot (24 lambs/ha). Swards were continuously stocked with lambs with a variable stocking rate to maintain a mean sward surface height of $6 \mathrm{~cm}$. Lambs grazing Aries HD plots consistently achieved higher liveweight gains over the experiment. Liveweight gain was higher on Aries HD than Yatsyn 1 during summer dry conditions $24 / 1 / 96$ to $4 / 3 / 96$ (50 vs. $31 \pm 7.8 \mathrm{~g}$ / day, $\mathrm{P}<0.035)$ and overall (104 vs. $84 \pm 4.6 \mathrm{~g} /$ day, $\mathrm{P}<0.103$ ). During summer on average $15 \%$ of lambs grazing Aries HD pasture were severely affected by perennial ryegrass staggers compared with $29 \%$ of lambs on Yatsyn 1 pastures $(\mathrm{P}<0.027)$. Information on pasture quality, alkaloid concentrations, and herbage intake is presented and discussed in relation to the differences in animal performance.
\end{abstract}

Keywords: alkaloids, animal evaluation, Aries HD perennial ryegrass, digestibility, lamb performance, Lolium perenne, ryegrass-endophyte association, ryegrass staggers

\section{Introduction}

To date there has been a lack of breeding progress for improved forage digestibility, although genetic variation for in vitro digestibility has been reported. Past breeding programmes emphasised other traits because the economic value of breeding for improved digestibility was not recognised, or other traits were considered to be more important (Vogel \& Sleper 1994). However, the cultivars that have been developed and released with improved forage quality have demonstrated a greater improvement in profitability than those offering similar increases in forage yield. Examples are selections in bermudagrass, switchgrass, wheatgrass and lucerne (Vogel \& Sleper 1994).

Gains from improved digestibility must be validated in animal experiments (Vogel \& Sleper 1994). Animal production experiments are the most direct means of detecting promising cultivars, assessing nutritive value continuously, providing economic assessment and testing persistence under commercial conditions (Laidlaw \& Reed 1993). They also provide an opportunity to detect adverse affects from the perennial ryegrass association with endophyte (Acremonium lolii). In addition they play a role in technology transfer by providing relevant information for farmers.

Wrightson Seeds Ltd selected Aries HD perennial ryegrass for improved forage quality over the crucial summer-autumn period. They have demonstrated organic matter digestibilities of 87.2 for Aries HD vs $84.6 \%$ for Yatsyn 1 (Wrightson Seeds 1997) under rotational cutting management at Kimihia Research Centre in Christchurch. The aim of the current experiment was to evaluate whether this demonstrated increase in digestibility could be translated into greater animal production.

\section{Materials and methods}

Clover-free swards of Aries HD and Yatsyn 1 were established on the Sheep and Beef Cattle Research Area, Massey University in autumn 1995, in a randomised complete block design with 3 blocks ( 0.33 ha/plot). The summer lamb finishing experiment began 11 December 1995 and concluded 25 April 1996.

A total of 58 Romney weaned wether lambs were selected for the experiment in late November 1995. Ten lambs were allocated to an initial slaughter group and their carcass weights were used to predict initial carcass weight of the remaining 48 lambs at the start of the experiment. These lambs were allocated to plots on 11 December in a stratified manner according to liveweight. Lambs were drenched monthly with Ivomec (ivomectin; Merk, Sharp and Dohme, NZ Ltd) to control internal parasites, and dipped with Vetrazin (cyromazine; CibaGeigy, NZ Ltd) in January to prevent fly strike.

Plots were grazed continuously to a sward surface height of $6 \mathrm{~cm}$ to ensure optimum feed intake and equal herbage allowance between plots (Hodgson 1990). This 
height was monitored twice per week with a sward stick, and maintained by adjusting lamb numbers. There were regular monthly applications of urea or Crop Master, equivalent to $147 \mathrm{~kg} \mathrm{~N} / \mathrm{ha}, 27.5 \mathrm{~kg} \mathrm{P} / \mathrm{ha}, 27.5$ $\mathrm{kg} \mathrm{K} / \mathrm{ha}$ and $20.8 \mathrm{~kg} \mathrm{~S} / \mathrm{ha}$ over the experiment. A sprinkler irrigation system was used in March during a severe dry spell. There were two applications of Versatill (clopyralid amine; DowElanco, NZ Ltd) at $1.5 \mathrm{l} / \mathrm{ha}$ to eliminate weeds and volunteer clover in the pasture.

Herbage mass was determined fortnightly by cutting six $0.1 \mathrm{~m}^{2}$ quadrats per plot to ground level. Botanical composition was also determined on bulked ground level samples from each plot. Pasture cuts to ground level and hand plucked samples were taken fortnightly for analysis of in vitro organic matter digestibility (Roughan et al. 1977), nitrogen (Kjeldahl procedure) and neutral detergent fibre content (Van Soest 1994). Monthly samples were also analysed for concentrations of lolitrem B, peramine and ergovaline by HPLC (Baker et al. 1993).

Lamb unfasted liveweight was recorded fortnightly. All lambs were slaughtered on 30 April 1996 and carcass weights and fat depth (GR) were recorded. Lambs were shorn one week before slaughter and greasy wool weighed. The wool yield (clean weight/greasy weight) was determined. Incidence of severe ryegrass staggers was recorded as the number of lambs carried to weighing each fortnight and was analysed using a chi-square test.

Herbage intake was measured from 19 to 25 April 1996 using intra-ruminal slow release chromium sesquioxide capsules (Captech New Zealand Ltd) as described by Parker et al. (1989). Faecal grab samples were oven dried, bulked across days on an equal dry weight basis and ground. Two sheep fistulated in the oesophagus were rotated among the swards, to collect samples of the herbage selected for calculation of organic matter digestibility. Chromium release rate was estimated by recovering capsules at slaughter.

Analysis of variance and repeated measures analysis were carried out using the General Linear Models (GLM) procedure of SAS (SAS Institute Inc. 1988). All statistical analyses were based on plot mean values with three replicates. Individual animal performance was calculated using data from core group animals and LSD analysis used where numbers were unbalanced.

\section{Results}

Mean herbage mass and sward height was similar over the experiment for the two cultivars (Table 2). Lamb stocking rate did not differ significantly between cultivars (Table 1). For both cultivars ryegrass was the principal component of the pasture on offer (over $80 \%$ live herbage). Clover content in the sward was negligible. The proportion of tillers infected with endophyte was over $90 \%$ in both cultivars.

Over the entire experiment Aries HD lambs gained $20 \mathrm{~g} /$ day (23\% advantage) more than Yatsyn 1 lambs, with a particular advantage in relative terms over the dry summer period (Table 1). From 24/1/96 to 4/3/96 there was a $61 \%$ advantage to Aries HD. Carcass weight gain of lambs grazing Aries HD was $32 \%$ higher than that of lambs grazing Yatsyn 1 ryegrass (Table 1). This resulted in a 9\% greater carcass weight at slaughter for Aries HD lambs over Yatsyn 1 lambs. Fat depth (GR score) was 24\% higher in Aries HD lambs at equivalent carcass weight. The better performance of Aries HD lambs was not reflected in a significant difference in wool production.

Table 1 Cultivar effects on liveweight gain, stocking rate, carcass weight gain and composition, and wool production of lambs.

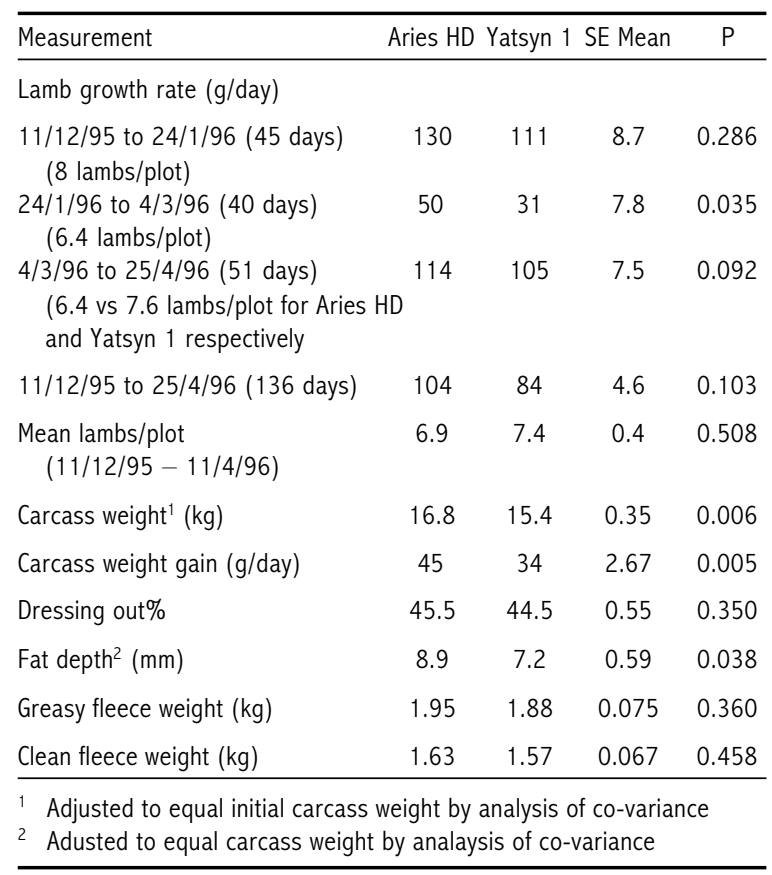

Chromium release rate from capsules was significantly greater in Aries HD lambs than in Yatsyn 1 lambs (Table 3). Herbage intake calculated using these release rates was $12 \%$ higher in Aries HD lambs, but this difference was not statistically significant, and was eliminated when intakes were re-calculated assuming the same for both treatments. In vitro organic matter digestibility of herbage samples from oesophageal 
fistulates did not differ significantly between cultivars. There was twice as much incidence of clinical ryegrass staggers among Yatsyn 1 lambs as in those grazing Aries HD pasture (Table 3).

In vitro organic matter digestibility, nitrogen and neutral detergent fibre content from herbage cuts or plucked samples did not differ significantly overall, and showed no indications of seasonal differences between cultivars (Table 4). Mean peramine content in Yatsyn 1 was $26 \%$ greater than in Aries HD samples (Table 5). Lolitrem B content did not differ between cultivars, with peak levels detected on 21/2/96 at 1.63 vs $1.56 \mathrm{ppm}$ for Aries HD and Yatsyn 1 samples respectively. Ergovaline contents in Aries HD herbage samples were consistently half those of Yatsyn 1 samples.

\section{Discussion}

Few experiments have evaluated grass cultivars within a single species, in terms of animal production under continuous stocking. However, in an assessment of contrasting perennial ryegrasses under continuous sheep stocking, Davies et al. $(1991,1993)$ demonstrated large and significant differences between cultivars in terms of lamb production and related them to differences in organic matter digestibility.

Wrightson Seeds Ltd have demonstrated higher levels of organic matter digestibility in Aries HD than in Yatsyn 1 pastures cut to grazing height every 4 weeks and allowed to regrow under cages. However, under continuous sheep grazing management we were unable to repeat this effect. In vitro organic matter digestibility from herbage cuts, pluck samples and oesophageal fistulates, and estimates of herbage nitrogen and neutral detergent fibre were all similar between cultivars. These conflicting results may reflect a greater opportunity for stem development in intermittently defoliated pastures. The lack of difference under set stocking was not owing to a dilution effect from weed species because perennial ryegrass content was high and similar for each cultivar. Similar estimates of herbage intake reflected similar nutritive value in the two cultivars.

The results suggest that seasonal contrasts in animal performance may have reflected differing alkaloid concentrations from the respective ryegrass-endophyte associations and effects on the incidence of ryegrass staggers. However, the liveweight gain advantage to Aries HD lambs was maintained when results for nonstaggering lambs were compared (49 vs $24 \pm 11.7 \mathrm{~g} /$ day for Aries HD and Yatsyn 1 lambs, respectively from 24/ $1 / 96$ to 4/3/96). Liveweight gains have been reduced on endophyte-infected ryegrass in the absence of clinical ryegrass staggers (Eerens et al. 1992). The ergovaline
Table 2 Cultivar effects on mean herbage mass, sward height, botanical composition and the proportion of tillers infected with endophyte.

\begin{tabular}{|c|c|c|c|c|}
\hline Sward measurements & Aries HD & Yatsyn 1 & SE Mean & $\mathrm{P}$ \\
\hline $\begin{array}{l}\text { Herbage mass } \\
(\mathrm{kg} \mathrm{DM} / \mathrm{ha})\end{array}$ & 2865 & 3108 & 517.6 & 0.385 \\
\hline $\begin{array}{l}\text { Sward height }(\mathrm{cm}) \\
4 / 1 / 96-29 / 4 / 96\end{array}$ & 6.68 & 7.37 & 1.391 & 0.166 \\
\hline $\begin{array}{l}\% \text { Ryegrass in live } \\
\text { herbage }\end{array}$ & 81.9 & 86.4 & 7.73 & 0.303 \\
\hline$\%$ Leaf in ryegrass & 71.8 & 70.9 & 1.27 & 0.407 \\
\hline $\begin{array}{l}\% \text { Endophyte infection } \\
\text { on } 14 / 5 / 96\end{array}$ & 90.8 & 91.7 & 3.58 & 0.885 \\
\hline
\end{tabular}

Table 3 Cultivar effects on herbage intake, capsule release rate, organic matter digestibility and incidence of ryegrass staggers.

\begin{tabular}{lcccc}
\hline Sward measurements & Aries HD & Yatsyn 1 & SE Mean & $P$ \\
\hline $\begin{array}{l}\text { Herbage intake (kg 0M/day) } \\
\text { (19-25 April 1996) }\end{array}$ & 1.18 & 1.05 & 0.046 & 0.162 \\
$\begin{array}{l}\text { Capsule release rate (mm/day) } \\
\quad(19-25 \text { April 1996, for }\end{array}$ & 1.10 & 1.03 & 0.021 & 0.0002 \\
$\quad$ intake calculation) & & & & \\
$\begin{array}{l}\text { Organic matter digestibility (\%) } \\
\text { (19-25 April 1996, for }\end{array}$ & 79.5 & 78.6 & 0.92 & 0.411 \\
$\quad$ intake calculation) & & & & \\
$\begin{array}{l}\text { Lambs with severe ryegrass } \\
\text { staggers (\% of lambs from } \\
\text { 24/1/96 to 4/3/96) }\end{array}$ & & & & \\
\hline
\end{tabular}

Table 4 Cultivar effects on herbage in vitro organic matter digestibility, nitrogen and neutral detergent fibre content.

\begin{tabular}{lcccc}
\hline Nutritive value estimates & Aries HD & Yatsyn 1 & SE Mean & \\
\hline Herbage cuts & & & & \\
$\quad$ Organic matter digestibility (\%) & 58.7 & 58.9 & 0.44 & 0.482 \\
$\quad$ Neutral detergent fibre (\%) & 59.9 & 60.1 & 0.96 & 0.825 \\
$\quad$ Nitrogen (\%) & 1.82 & 1.75 & 0.064 & 0.219 \\
Pluck samples & & & & \\
$\quad$ Organic matter digestibility (\%) & 66.3 & 67.1 & 2.1 & 0.632 \\
$\quad$ Neutral detergent fibre (\%) & 53.9 & 53.5 & 1.18 & 0.650 \\
$\quad$ Nitrogen (\%) & 2.65 & 2.74 & 0.111 & 0.303 \\
\hline Mean from five cuts to ground level-17/12/95 to & $19 / 4 / 96$ & \\
\hline
\end{tabular}

Table 5 Herbage endophyte alkaloid estimates (ppm).

\begin{tabular}{lcccc}
\hline Alkaloid & Aries HD & Yatsyn 1 & SE Mean ${ }^{1}$ & $P$ \\
\hline Lolitrem B & 0.95 & 0.97 & 0.197 & 0.888 \\
Peramine & 11.85 & 15.92 & 0.992 & 0.023 \\
Ergovaline & 0.23 & 0.42 & 0.042 & 0.026 \\
\hline
\end{tabular}

1 Mean from five cuts to ground level $-17 / 12 / 95$ to $19 / 4 / 96$ 
content detected in Aries HD herbage samples was consistently half that of Yatsyn 1 samples.

Lolitrem B has been regarded as the major alkaloid responsible for ryegrass staggers (Gallagher et al. 1984), but levels detected in the two cultivars were similar. Piper \& Fletcher (1990) concluded that ergovaline was not involved with the staggers syndrome. Ergovaline has been associated with reduced liveweight gain in tall fescue (Belesky et al. 1988; Debessai et al. 1993) and perennial ryegrass (Piper et al. 1990; Fletcher et al. 1991; Fletcher \& Sutherland 1993), elevated body temperature, respiration rate and reduced serum prolactin levels (Fletcher 1993). Also ryegrass-endophyte associations free of, or with low levels of lolitrem B but with significant levels of the tremogenic mycotoxin paxilline have been found to cause ryegrass staggers (Fletcher 1991; Fletcher \& Sutherland 1993; Fletcher et al. 1993).

Levels of pasture production, estimated indirectly from the stocking rate required to maintain swards at 6 $\mathrm{cm}$ surface height, were similar for the two cultivars. This probably reflects the fact that peramine levels in both cultivars were greater than $10 \mathrm{ppm}$ (Table 2), the threshold thought to deter feeding by adult and larval Argentine stem weevil (Rowan et al. 1990). Endophyte infection levels were also high and consistent between cultivars.

\section{Conclusions}

Liveweight gain differences between perennial ryegrass cultivars can be owing to quality factors, the association with endophyte, or both. Under continuous sheep grazing management the higher liveweight and carcass weight gains achieved on Aries HD pasture than on Yatsyn 1 pasture could not be attributed to any difference in herbage nutritive value. Better animal performance in this experiment reflected interrelated effects of alkaloid concentrations and ryegrass staggers. This highlights the need for animal evaluation experiments in assessing not only nutritive value, but also the effects of cultivarendophyte associations which influence the production and balance of alkaloids.

\section{ACKNOWLEDGEMENTS}

This research was funded by Wrightson Seeds Ltd. The C. Alma Baker Trust is also acknowledged for providing stipend support. The authors wish to thank Mr G.S. Purchas (Animal Science Department, Massey University) and Ms L. Watt (Manager Sheep and Beef Cattle Research Block) for technical support. AgResearch, Palmerston North is also acknowledged for providing alkaloid analysis.

\section{REFERENCES}

Baker, D.J.; Davies, E.; Lane, G.A.; Latch, G.C.M.; Nott, H.M.; Tapper, B.A. 1993. Effect of water deficit on alkaloid concentrations in perennial ryegrass endophyte associations. Proceedings of the Second International Symposium on Acremonium/ Grass Interactions: 67-71

Belesky, D.P.; Stuedemann, J.A.; Plattner, R.D.; Wilkinson, S.R. 1988. Ergopeptine alkaloids in grazed tall fesuce. Agronomy journal 80: 209-212.

Davies, D.A.; Fothergill, M. Jones, D. 1991. Assessment of contrasting perennial ryegrasses, with and without white clover, under continuous sheep stocking in the uplands. 3. Herbage production, quality and intake. Grass and forage science 46: 39-49.

Davies, D.A.; Fothergill, M.; Jones, D. 1993. Assessment of contrasting perennial ryegrasses, with and without white clover, under continuous sheep stocking in the uplands. 5. Herbage production, quality and intake in years 4-6. Grass and forage science 48: 213-222.

Debessai, W.; Loick, B.R.; Cheeke, P.R. 1993. Effects of feeding endophyte-infected tall fescue seed on lamb performance and serum prolactin. Proceedings of the Second International Symposium on Acremonium/Grass Interactions: 111-113.

Eerens, K.P.J. 1992. The ryegrass endophyte in a cool moist environment. Proceedings of the New Zealand Grassland Association 54: 157-160.

Fletcher, L.R.; Popay, A.J.; Tapper, B.A. 1991. Evaluation of several lolitrem-free endophyte/ perennial ryegrass combinations. Proceedings of the New Zealand Grassland Association 53: 215-219.

Fletcher, L.R. 1993. Grazing ryegrass/endophyte associations and their effect on animal health and performance. Proceedings of the Second International Symposium on Acremonium/Grass Interactions: Plenary Papers: 89-93.

Fletcher, L.R.; Garthwaite, I.; Towers, N.R. 1993. Ryegrass Staggers in the Absence of Lolitrem B. Proceedings of the Second International Symposium on Acremonium/Grass Interactions : 119-212.

Fletcher, L.R.; Sutherland, B.L. 1993. Liveweight change in lambs grazing perennial ryegrasses with different endophytes. Proceedings of the Second International Symposium on Acremonium/Grass Interactions : 125-127.

Gallagher, R.T.; Hawkes, A.G.; Steyne, P.S.; Vleggaar, R. (1984). Tremorgenic neurotoxins from perennial ryegrass causing ryegrass staggers disorder of livestock: structure and elucidation of lolitrem B. Journal of chemical society, communications (London): 614-616. 
Hodgson, J. 1990. Sward conditions, herbage intake and animal performance. In: Grazing management - science into practice. USA: Longman Scientific and Technical.

Laidlaw, A.S.; Reed, K.F.M. 1993. Plant improvement: the evaluation and extension processes. Proceedings of the XVII International Grassland Congress: 385392.

Parker, W.J.; McCutcheon, S.N.; Carr, D.H. 1989. Effect of herbage type and level of intake on the release of chromic oxide from intra-ruminal controlled release capsules in sheep. New Zealand journal of agricultural reseach 32: 537-546.

Piper, E.L.; Fletcher, L.R. (1990). Influence of a dopamine antagonist on ryegrass staggers. Proceedings of the International Symposium on Acremonium/Grass Interactions: 248-249.

Roughan, P.G.; Holland, R. 1977. Predicting in-vivo digestibilities of herbages by exhaustive enzyme hydrolysis of cell walls. Journal of the science of food and agriculture 28: 1057-1106.

Rowan, D.D.; Dymock, J. J.; Brimble, M.A. 1990. Effect of fungal metabolite peramine and analogs on feeding and development of Argentine stem weevil (Listronotus bonariensis). Journal of chemical ecology 16: 1683-1695.

SAS, 1988: SAS user's guide, release 6.03 edition. Statistical Analaysis System Institue. Cary, North Carolina, USA.

Van Soest, P.J. (1994). Nutritional ecology of the ruminant. Ithaca and London: Cornell University Press.

Vogel, K.P.; Sleper, D.A. 1994. Alteration of plants via genetics and plant breeding. In: Forage quality, evaluation, and utilisation. University of Nebraska.

Wrightson Seeds Ltd, 1997. Pasture Options: 5. 
